\title{
IMMUNOCYTOCHEMICAL DEMONSTRATION OF PROTEIN KINASE A IN THE RAT HIPPOCAMPUS
}

\author{
Gerd POEGGeL ${ }^{1}$, Hans LUPPA ${ }^{2}$, Heike BRANDT ${ }^{2}$ \\ AND ROLAND VETTER ${ }^{3}$
}
Academy of Sciences ${ }^{1}$, Institute for Neurobiology and Brain Research, Leipziger Str. 44, 3090-Magdeburg, GDR, Karl Marx University Leipzig ${ }^{2}$, Section of Biosciences, Talstr. 33, 7010-Leipzig, GDR, and Academy of Sciences ${ }^{3}$, Central Institute of Cardiovascular Research, Lindenberger Allee 70, 1115-Berlin-Buch, GDR

Received for publication August 4, 1989 and in revised form September 26, 1989

The protein kinase A was demonstrated at the electron microscopic level in the rat hippocampus by an immunocytochemical method. The enzyme was localized in neurons as well as in glial cells. Immunocytochemical reactions were found in the cytoplasm of the cells, on the endoplasmic reticulum and in nuclei. Strong staining was detected in synapses, in the postsynaptic thickenings and on the microtubules of dendrites. No staining was found on axonal microtubules and in oligodendrocytes. Astroglial cells were regularly stained, somata as well as processes contained reaction product.

Knowledge of the intracellular localization of enzymes can increase our understanding about the regulation of different cellular processes. The protein kinase A (PKA) is the only known intracellular receptor for cyclic AMP $(5,15)$. PKA regulates a great number of biochemical processes by the phosphorylation of several target proteins $(1,3,11)$. Because the protein phosphorylation is a process, catalyzed by a number of enzymes, the enzyme histochemical localization of the PKA seems to be impossible. For this reason we prepared an antiserum, directed to the catalytic subunit of bovine heart PKA. The antiserum cross reacted with the brain enzyme and was used for the detection of PKA in the rat hippocampus.

\section{MATERIALS AND METHODS}

The antiserum was raised in rabbits against the catalytic subunit of bovine heart PKA. Specificity and cross reactivity with the brain enzyme were tested by immunoblotting. Wistar rats were anaesthetized and perfused with a mixture of $4 \%$ freshly prepared paraformaldehyde and $0.25 \%$ glutaraldehyde in $100 \mathrm{mM}$ phosphate buffered saline $\mathrm{pH}$ 7.4. After removing the brain, the hippocampi were prepared and immersion fixed for a further hr. With a vibratome, sections (50 $\mu \mathrm{m}$ in thickness) were cut and washed overnight. The washing procedure was followed by a reduction

Abbreviations: PKA: protein kinase A, PDE: cyclic nucleotide phosphodiesterase, ATP: adenosine triphosphate. 
with $1 \% \mathrm{Na}\left(\mathrm{BH}_{4}\right)$ and the immunocytochemical procedure was carried out as described by Poeggel et al. (14). The antiserum was used in dilutions of $1: 1000-1: 2000$. All solutions contained $0.1 \%$ Triton X-100. Control reactions were performed with a rabbit normal serum instead of the antiserum and with antiserum, preabsorbed with the antigen,

\section{RESULTS}

The immunocytochemical reaction for PKA was detected in neurons as well as in glial cells. On the subcellular level the staining was found in the cytoplasm of the cells, often attached to intracellular membranes like endoplasmic reticulum and outer nuclear envelope (Fig. 1). The strongest staining was found on microtubules of the somata and dendrites of neurons (Figs. 3a, b). In the synaptic region, mainly the postsynaptic thickening reacted with the antiserum (Fig. 2). Often a reaction in glial cell processes separating neuronal elements was found (Fig. 4). In the area surrounding capillaries sometimes only the glial cell processes reacted (Fig. 5), sometimes the endothelial cells were stained and sometimes glial cell processes and endothelial cells contained reaction product (Fig. 6). Control reactions with rabbit normal serum (Fig. 7) and with antiserum, preabsorbed with the PKA-preparation were consistently negative. The ultrastructure, especially membranes, was negatively influenced by the Triton X-100.

\section{DISCUSSION}

Because of the universal reaction, catalyzed by PKA (phosphate transfer to proteins), which is catalyzed also by a number of other protein kinases $(7,10,11,18)$, the specific histochemical demonstration of this enzyme by its chemical reaction seems to be impossible. The immunohistochemical method can overcome these difficulties. The regulatory $(6,8)$ as well as the catalytic subunits $(6)$ were demonstrated in several tissues by immuno-gold methods.

We found a strong inhibition of the antibody reaction by the glutaraldehyde. This inhibition could only partly reversed by $\mathrm{Na}\left(\mathrm{BH}_{4}\right)$ reduction. The ultrastructure was negatively influenced by the Triton $X-100$, which was necessary to improve the antibody penetration. Nevertheless, the PKA could be localized in neurons, glial cells and endothelium. No reaction occurred in oligodenderocytes, whereas astrocytes and their processes were strongly stained (Figs. 4-6). The strongest reaction was found in cytoskeletal elements of the dendrites of neurons (Figs. 3a, b). The regulatory subunit of the PKA is bound to microtubule associated proteins [MAPs] (7), and is thereby localized near important substrate proteins and concentrates the catalytic subunit near its target proteins. As much as one third of total cytosolic PKA in brain is bound via the regulatory subunit to the microtubule-associated protein 2 [MAP 2] (9). MAP 2 is a dendritic microtubule associated protein, its occurrence is restricted to the somata and dendrites of neurons and does not occur in axons. Besides other second messenger-regulated protein kinases, PKA is selectively concentrated in denderites and there is no clear evidence that axonal MAP's can be phosphorylated by second messenger dependent protein kinase [for review see (2)]. This is in agreement with our results that PKA was never localized in axons, but a strong staining was 


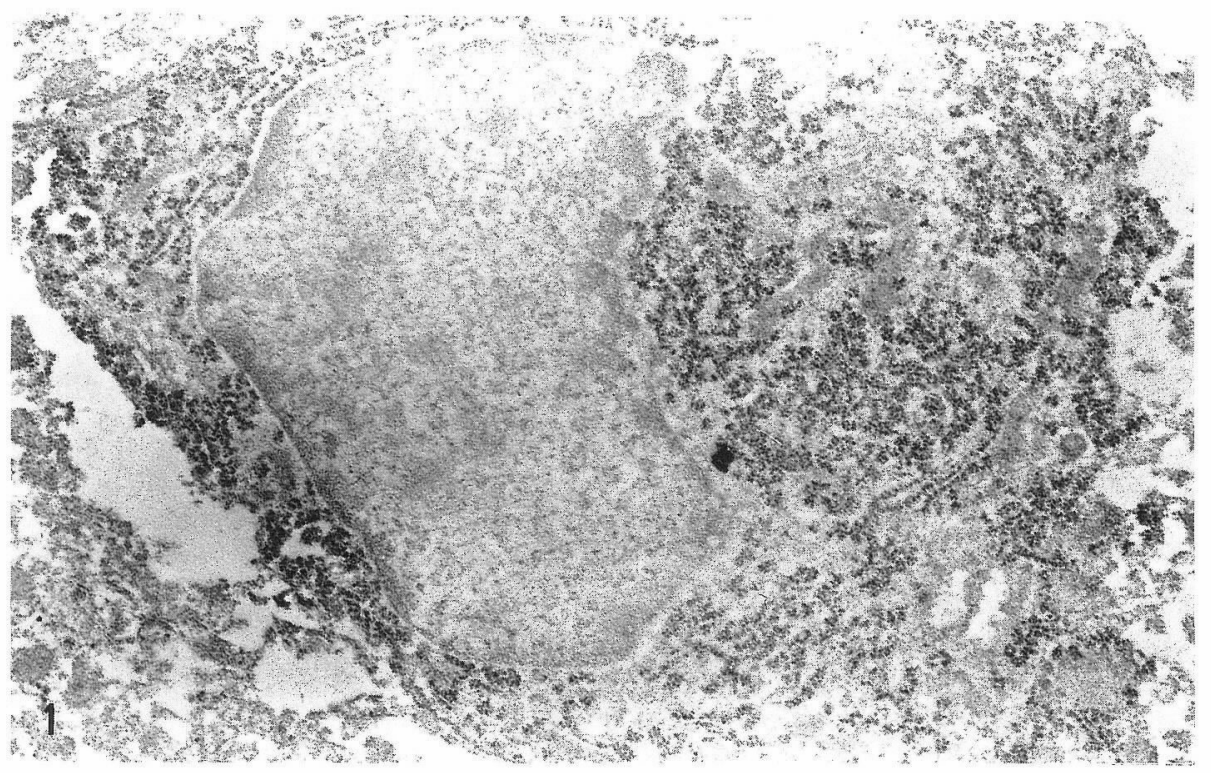

FIG. 1. Cellular localization of PKA-immunoreactivity. $\quad \times 23,000$

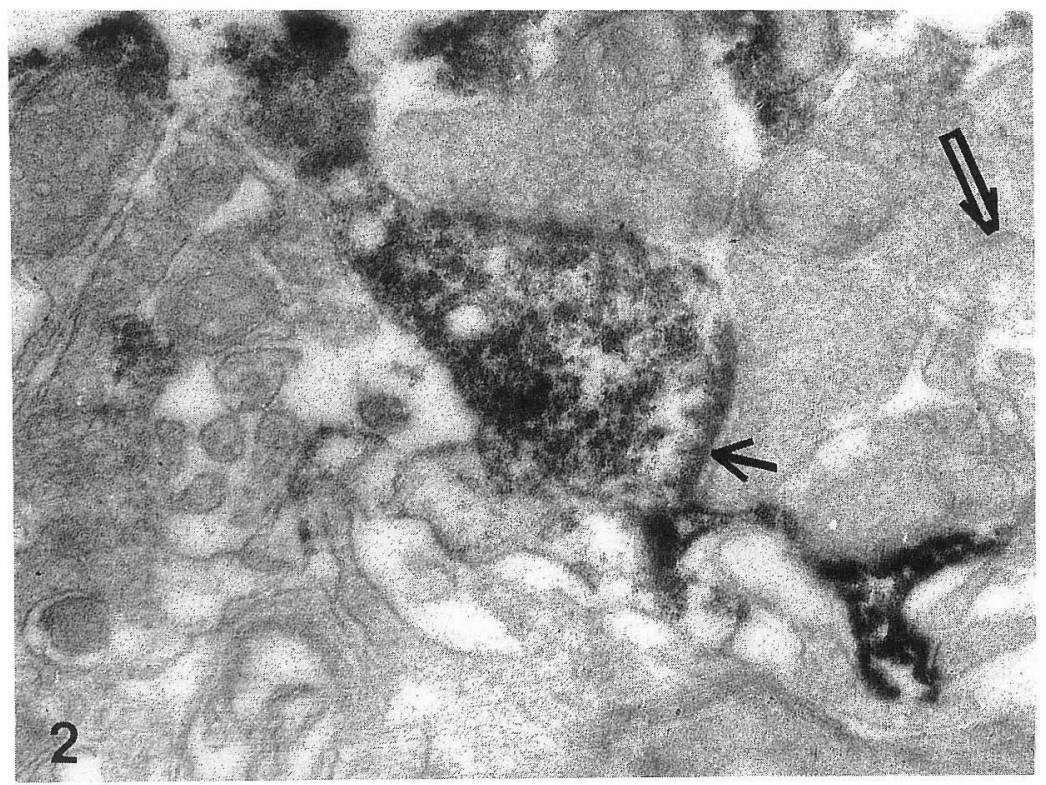

FIG. 2. Localization of reaction product in synapses. Note the staining of postsynaptic thickenings $(\longrightarrow)$ besides unstained postsynaptic thickenings $(\Longrightarrow)$, partly on the same spine. No poststaining. $\times 52,000$ 

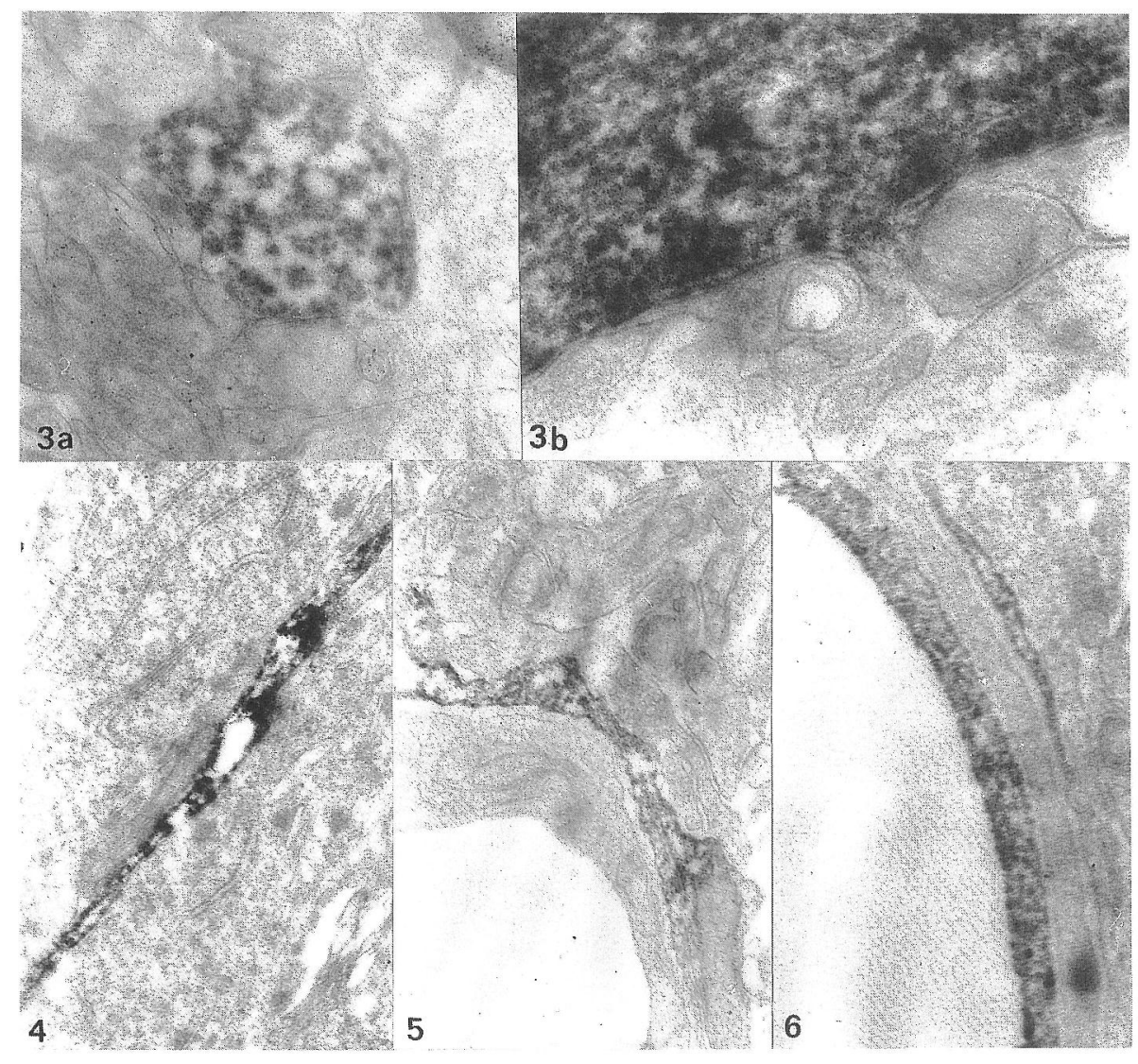

FIgs. 3a, b. Localization of PKA-like immunoreactivity in dendrites. Note the strong reaction of microtubules. No poststaining. a. $\times 41,000$ b. $\times 74,000$

FIG. 4. Staining of a glial cell process, separating neuronal elements. Poststained with lead citrate. $\times 36,000$

FIG. 5. PKA-like immunoreactivity in the surrounding of capillaries, only glial cell processes were reactive. No poststaining. $\times 53,000$

FIG. 6. Reaction of endothelial cells and glial cell processes. No poststaining. $\times 72,000$

found in cytoplasm and dendritic microtubules. The postsynaptic staining (Fig. 2) could be due to the association of PKA with synaptic proteins $(4,17)$ and the regulation of postsynaptic processes. In Fig. 2 it is seen that besides reactive synapses $(\longrightarrow)$ nonreactive synapses occur, even on the same spine $(\square)$. This is a hint for differently regulated postsynaptic events. The functions of glial cells seem to be partly regulated by second messenger-coupled processes, because besides the PKA (Figs. 46) the occurrence of other second messenger-related enzymes in astroglia is described (12-14). Figs. 5, 6 demonstrate a heterogenous pattern of PKA in capillaries, because not all endothelial cells were reactive. Such a heterogeneity of the enzymatic equipment of the capillary endothelium was previously described (16). 


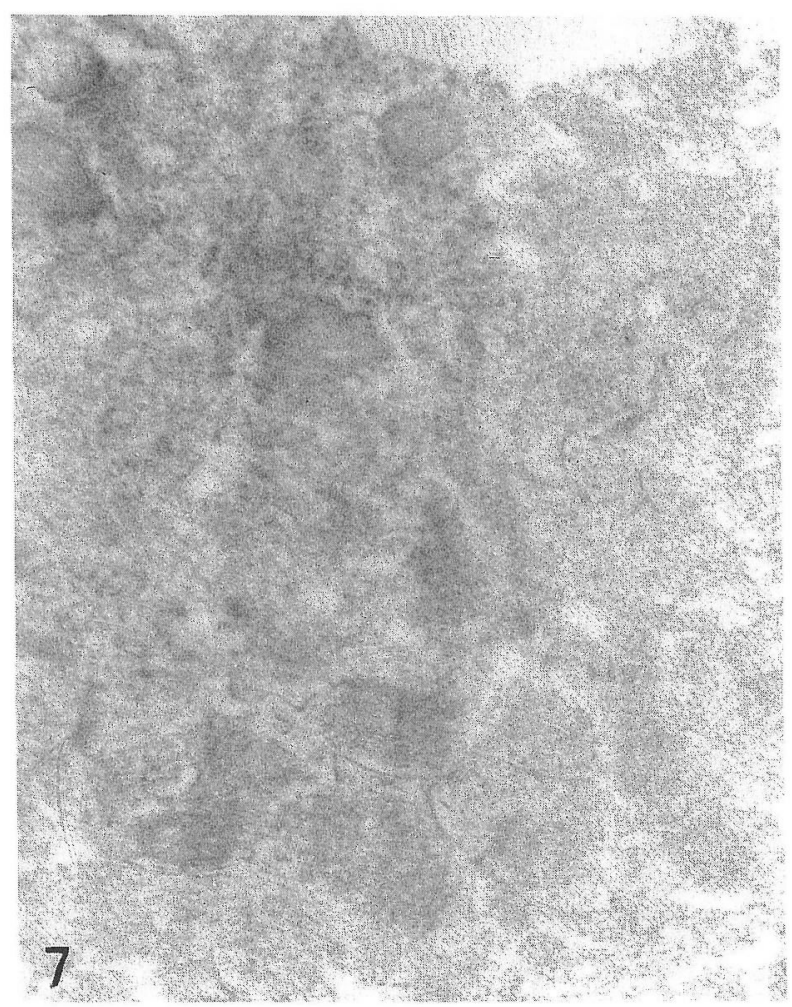

FIG. 7. Control reaction with a rabbit normal serum. No poststaining. $\times 45,000$

\section{ACKNOWLEDGMENTS}

The authors thank Mrs. Herold for her excellent technical assistance.

\section{REFERENGES}

1. De Camilli, P., Moretti, M., Donini, D. S., Walter, U. and Lohmann, S. M.: Heterogeneous distribution of the cAMP receptor protein RII in the nervous system: Evidences for its intracellular accumulation on microtubules, microtubule-organizing centres, found in the area of the Golgi complex. J. Cell Biol. 103; 189-203, 1986.

2. De Camilli, P., Solimena, M., Moretti, M. and Navone, F.: Sites of action of second messengers in the neuronal cytomatrix. In Intrinsic Determinants of Neuronal Form and Fuction; Neurology and Neurobiology, vol. 37; ed. by R. J. Lasek, and M. M. Black, Alan, R. Liss Inc. New York, 1988, p. 487-520.

3. Furuki, Y., Yamamoto, T., Guild, S. and Kebabian, J. W.: Substrates for cAMP-dependent protein kinase in the rat pituitary gland. Cell. Mol. Neurobiol. 8; 71-83, 1988.

4. Greengard, P.: Possible role for cyclic nucleotides and phosphorylated membrane proteins in postsynaptic actions of neurotransmitters. Nature 260; 101-108, 1976.

5. Hofmann, F. and Schultz, G.: Regulation cellulärer Funktionen durch Proteinphosphorylierungen. Drug. Res. 30; 1991-1995, 1980. 
6. Joachim, S. and Schwoch, G.: Immunoelectron microscopic localization of catalytic and regulatory subunits of cAMP-dependent protein kinase in the parotid gland Eur. J. Cell Biol. 46; 491-498, 1988.

7. Kennedy, M. B.: Structures of neuronal protein kinases. In Molecular Biology of the Human Brain, ed. by E. G. Jones, Alan R. Liss Inc., New York, 1988, p. 79-93.

8. Lieberman, S. J., Wasco, W., McLeod, J., Satir, P. and Orr, G. A.: Immunogold localization of the regulatory subunit of a type II cAMP-dependent protein kinase tightly associated with mammalian sperm flagella. J. Cell Biol. 107; 1809-1816, 1988.

9. Lohmann, S. M., DeCamilli, P. and Walter, U.: Type II cAMP-dependent protein kinase regulatory subunit-binding proteins. Initiation and termination of cyclic nucleotide action. Meth. Enzymol. 159; 183-192, 1988.

10. Nairn, A. C., Hemmings, H. C. and Greengard, P.: Protein kinases in the brain. Ann. Rev. Biochem. 54; 931-976, 1985.

11. Nestler, E. J. and Greengard, P.: Protein phosphorylation and the regulation of neuronal function. In Basic Neurochemistry, Molecular, Cellular, and Medical Aspects, 4th ed., by G. J. Siegle, B. W. Agranoff, R. W. Albers, and P. B. Molinoff, Raven Press, New York, 1989, p. 373-398.

12. Poeggel, G. and Luppa, H.: Histochemical demonstration of guanylate cyclase activity in the rat hippocampus by the electron microscope. Basic Appl. Histochem. in press, 1989.

13. Poeggel, G., Luppa, H. and Ludwig, A.: Histochemistry of cyclic nucleotide phosphodiesterase in nervous tissue. II. Immunohistochemical investigations. Acta histochem. cytochem. 20; 381-386, 1987.

14. Poeggel, G., Luppa, H. and Schmidt, A.: Histochemistry of cyclic nucleotide phosphodiesterase in nervous tissue. IV. Immunocytochemical investigations. Acta histochem. cytochem. 21; 413-421, 1988.

15. Saraswat, L. D., Ringheim, G. E., Bubis, J. and Taylor, S. S.: Deletion mutants as probes for localizing regions of subunit interaction in cAMP-dependent protein kinase. J. Biol. Chem. 263; 18241-18246, 1988.

16. Schnabel, R., Lojda, Z., Julis, I. and Luppa, H.: Heterogeneity of the enzymatic equipment of the capillary endothelium in the mouse brain with special reference to membrane proteases. Biol. Zent. bl. 107; 175-180, 1988.

17. Sieghart, W., Forn, J., Schwartz, R., Coyle, J. T. and Greengard, P.: Neuronal localization of specific brain phosphoproteins. Brain Res. 156; 345-350, 1978.

18. Sommercorn, J. and Krebs, E. G.: Classification of protein kinases into messenger dependent and independent kinases. In Advantages in Post-translational Modifications of Proteins and Aging, ed. by V. Zappia, P. Galletti, R. Porta, and F. Wold, Plenum Publishing Corporation, 1988, p. 403-415. 